\title{
Cushing's syndrome due to ectopic ACTH secretion
}

\author{
Zespół Cushinga w przebiegu ektopowego wydzielania ACTH \\ tukasz Cieszyński, Monika Berendt-Obołończyk, Michał Szulc, Krzysztof Sworczak \\ Department of Endocrinology and Internal Medicine, Medical University of Gdansk
}

\begin{abstract}
Cushing's syndrome (CS) is defined as a constellation of clinical signs and symptoms occurring due to hypercortisolism. Cortisol excess may be endogenous or exogenous. The most common cause of CS is glucocorticoid therapy with supraphysiological (higher than in the case of substitution) doses used in various diseases (e.g. autoimmune). One possible CS cause is ectopic (extra-pituitary) ACTH secretion (EAS) by benign or malignant tumours. Since its first description in 1963, EAS aetiology has changed, i.e. as well as small cell lung cancer (SCLC), higher incidence in other malignancies has been reported. Ectopic ACTH secretion symptoms are usually similar to hypercortisolism symptoms due to other causes. A clinical suspicion of CS requires laboratory investigations. There is no single and specific laboratory test for making a CS diagnosis, and therefore multiple dynamic tests should be ordered. A combination of multiple laboratory noninvasive and invasive tests gives $100 \%$ sensitivity and $98 \%$ specificity for EAS diagnosis. If the EAS is caused by localised malignancy, surgery is the optimal treatment choice. Radical tumour excision may be performed in $40 \%$ of patients, and $80 \%$ of them are cured of the disease. The authors present an interesting clinical case of EAS, which is always a huge diagnostic challenge for clinicians. (Endokrynol Pol 2016; 67 (4): 458-464)
\end{abstract}

Key words: Cushing `s syndrome; ectopic ACTH secretion; hypercortisolism; neuroendocrine neoplasm

\section{Streszczenie}

Zespół objawów klinicznych: podmiotowych i przedmiotowych, które wynikają z hiperkortyzolemii określa się mianem zespołu Cushinga (CS). Nadmiar kortyzolu w organizmie może mieć źródło egzo- lub endogenne. Powszechnie uważa się, że najczęstszą przyczyną CS jest terapia glikokortykosteroidem $\mathrm{w}$ dawkach farmakologicznych, większych niż substytucyjne, z powodu różnych chorób, na przykład tkanki łącznej. Jedną z możliwych przyczyn CS jest ektopowe, czyli poza przysadkowe wydzielanie ACTH, przez nowotwór łagodny lub złośliwy. Od czasu pierwszego opisu w 1963 roku, etiologia ektopowego wydzielania ACTH uległa istotnej zmianie, poza drobnokomórkowym rakiem płuca (SCLC) opisano inne nowotwory, których częstość znacząco wzrosła. Symptomatologia CS w przebiegu ektopowego wydzielania ACTH najczęściej odpowiada objawom hiperkortyzolemii spotykanym u chorych z powodu innej przyczyny. Podejrzenie kliniczne CS wymaga weryfikacji laboratoryjnej. Nie ma swoistego, pojedynczego badania, które by potwierdziło CS w przebiegu ektopowego wydzielania ACTH, z tego względu należy posiłkować się szeregiem testów. Połączenie wielu badań laboratoryjnych, w tym inwazyjnych, sprawia, że czułość rozpoznania ektopowego wydzielania ACTH sięgnąć może 100\%, przy swoistości 98\%. W przypadku lokalizacji ogniska pierwotnego leczenie operacyjne jest postępowaniem optymalnym. Radykalne leczenie można zastosować u $40 \%$ chorych, z czego około $80 \%$ udaje się wyleczyć. Przedstawiony przypadek ektopowego wydzielania ACTH stanowi przykład licznych trudności diagnostycznych dla lekarza praktyka. (Endokrynol Pol 2016; 67 (4): 458-464)

Słowa kluczowe: zespół Cushinga; ektopowe wydzielanie ACTH; hiperkortyzolemia; nowotwór neuroendokrynny

\section{Introduction}

Cushing's syndrome (CS) is defined as a constellation of clinical signs and symptoms occurring due to hypercortisolism. Cortisol excess may be endogenous or exogenous. The most common cause of CS is glucocorticoid therapy with supraphysiological (higher than in the case of substitution) doses used in various diseases (e.g. autoimmune) [1]. Clinical evaluation, diagnostic approach, and treatment of endogenous CS is a significant endocrine concern. Morbidity of this rare disease is 2.5 cases per million per year [2]. One possible CS cause is ectopic (extra-pituitary) ACTH secretion by benign or malignant tumours. The first report of extra-pituitary
ACTH secretion due to malignancy was described in 1928 by Brown [3]. The term of ectopic ACTH secretion (EAS) was proposed by Liddle in 1963; it was based mainly on patients with small cell lung cancer (SCLC) [4]. Since that time EAS aetiology has changed, i.e. as well as SCLC, higher incidence in other malignancies has been reported [5-7].

\section{Epidemiology}

The most common cause of endogenous CS is an ACTH secreting pituitary adenoma defined as Cushing's disease. It is estimated that it causes $70 \%$ of endogenous CS cases. EAS is diagnosed in $10 \%$ of endogenous CS 
Table I. Causes of CS

\begin{tabular}{ll}
\hline ACTH-dependent CS & \\
\hline Cushing's disease & $70 \%$ \\
\hline Ectopic ACTH secretion & $10 \%$ \\
\hline Other & $5 \%$ \\
\hline ACTH-independent CS & $10 \%$ \\
\hline Adrenal adenoma & $5 \%$ \\
\hline Adrenal cancer & $\sim 2 \%$ \\
\hline Other
\end{tabular}

patients; other causes of CS are listed in Table I [8-10]. Cushing's disease is more common in women, but EAS has an equal incidence in both sexes or even is more common in men. The average age at Cushing's disease diagnosis is $30-40$ years, and EAS is diagnosed in 45-50-year-olds.

Most of EAS tumours are malignant and are derived from amine precursor uptake and decarboxylation (APUD) cells of diffuse endocrine neoplasms (DES) and constitute neuroendocrine neoplasms (NENs). Due to different classification and better diagnostic methods in the last few decades, patients with SCLC have become a smaller group of EAS cases nowadays. The most common causes of EAS are bronchial tract NENs (25\%), lung cancers $(20 \%)$, thymic NENs $(11 \%)$, pancreatic NENs $(8 \%)$, medullary cancers $(6 \%)$, and phaeochromocytomas $(5 \%)$. The incidence of malignancies arising from cells other than endocrine is $6-8 \%[7,8,11]$. Further, in many patients the origin of malignancy is unknown (even up to $20 \%$; the most commonly finally diagnosed tumour is a bronchial NEN) $[5,12,13]$. Causes of EAS are mentioned in Table II $[6,7,11,14-17]$.

\section{Symptomatology}

Ectopic ACTH secretion symptoms are usually similar to hypercortisolism symptoms due to other causes. They are related to hypercortisolism duration, severity of cortisol excess, individual susceptibility to glucocorticoids, and the progression of malignancy. The most common abnormalities are listed in Table III [8].

Other signs of CS are: buffalo hump, fat deposits in supraclavicular areas, exophthalmos, deep and broad purple striae, impaired wound healing, chronic skin infections like mycosis, acne, and sebaceous skin changes, muscle atrophy, peripheral oedema, and thromboembolic events $[1,18]$. In EAS caused by a malignancy, clinical features may be different from those found in other hypercortisolism cases due to fast disease progression and higher ACTH levels and consequently greater
Table II. Causes of EAS

\begin{tabular}{lll}
\hline Ectopic ACTH secretion & & \\
\hline Common & Rare & Very rare \\
\hline Bronchial NEN & Ovarian cancer & $\begin{array}{l}\text { Oesophageal } \\
\text { cancer }\end{array}$ \\
\hline Lung cancer & Colorectal cancer & Kidney cancer \\
\hline Thymic NEN & Prostate cancer & Hepatocarcinoma \\
\hline Pancreatic/gastrointestinal & Cervical cancer & Breast cancer \\
tract NEN & & \\
\hline Medullary thyroid cancer & Neuroblastoma & Salivary gland \\
& & tumour \\
\hline Pheochromocytoma & & Pleural \\
& & mesothelioma \\
\hline & & Lymphomas \\
\hline & & Malignant \\
& & melanoma \\
\hline & Ovarian and \\
& & testicular tumour \\
\hline & Laryngeal cancer \\
\hline
\end{tabular}

Table III. Most common signs and symptoms of CS

\begin{tabular}{lc}
\hline Signs and symptoms & Incidence (\%) \\
\hline Obesity/weight gain & 95 \\
\hline Plethora & 90 \\
\hline Moon face & 90 \\
\hline Libido decrease & 90 \\
\hline Thin skin & 85 \\
\hline Dysmenorrhoea & 80 \\
\hline Arterial hypertension & 75 \\
\hline Hirsutism & 75 \\
\hline Mental disorders & 70 \\
\hline Easy bruising & 65 \\
\hline Prediabetic state and diabetes mellitus & 60 \\
\hline Muscle weakness & 60 \\
\hline Osteoporosis/Low energy fractures & 50 \\
\hline Nephrolithiasis & 50 \\
\hline
\end{tabular}

cortisol hypersecretion. Patients with SCLC or other aggressive malignancy present severe hypokalaemia and also demonstrate general signs and symptoms as well as those related to local and distant metastases. Concerning other differences, EAS incidence is higher in men, patients have shorter medical histories, and the following may be present: melanoderma, decrease in body weight or no weight gain, lack of typical CS fat tissue distribution, more often and more severe infections and psychiatric disorders [7, 19-22]. There 
are no specific signs useful in the differential CS diagnosis (except rapid development of symptoms/signs), which is why it is based on additional laboratory and radiology tests.

\section{Diagnosis}

A clinical suspicion of CS requires laboratory investigations. In the first step hypercortisolism must be confirmed, the next step is a differential diagnostic work-up discerning between an ACTH-dependent and independent CS. In case of elevated ACTH levels, the differentiation between Cushing's disease and EAS must be performed [6, 8]. In daily practice this clear diagnostic scheme is a huge clinical challenge. There is no single and specific laboratory test for making a CS diagnosis and therefore multiple dynamic tests should be ordered. Combination of multiple laboratory noninvasive and invasive tests gives $100 \%$ sensitivity and $98 \%$ specificity for EAS diagnosis [20]. Sometimes cortisol excess is not related to CS and may be observed in depression, alcohol abuse, anorexia nervosa, and pregnancy (pseudoCS). It can also be a consequence of infection, stress, or drug administration, e.g. oral contraceptives (OC). Periodic cortisol hypersecretion (in cyclical CS) is yet another diagnostic problem because patients suffering from it exhibit normal laboratory results during periods without cortisol excess. The greatest diagnostic problem is small ACTH-producing tumours (pituitary or extra-pituitary), with a size lower than the sensitivity of imaging techniques. Subsiding of hypercortisolism symptoms after tumour removal and positive immunochemical staining for ACTH or precursor (POMC) in excised tissue indicates an EAS diagnosis. Such a diagnosis may not be considered a certainty in the case of a primarily disseminated malignancy (with no chance of cure) and heterogeneity of the population of malignant cells (leading to a false negative ACTH staining) [14].

The available laboratory tests used for CS diagnosis are: 24 -hour free urine cortisol excretion, $1 \mathrm{mg}$ overnight dexamethasone suppression test (ONDST), late evening salivary free cortisol, night plasma serum cortisol, verification of the rhythm of circadian cortisol secretion (serum cortisol concentration in the morning and in the evening), low- and high-dose dexamethasone cortisol suppression tests, human CRH and desmopressin test, and finally, bilateral inferior petrosal sinus sampling (BIPS), which is not routinely performed in Poland. Of all those listed the most valuable first-line test is $1 \mathrm{mg}$ ONDST, late salivary cortisol or 24-hour UFC (at least two collections). CRH test and BIPSS (if available) are essential in differentiating Cushing`s disease from EAS.
Urinary free cortisol (UFC) is a fraction of total cortisol, which is not bound with proteins. Urinary free cortisol excess is seen in CS and also pseudo-CS. Commonly used OC, which increases serum cortisol concentration, influences UFC minimally (since it stimulates cortisol binding globulin synthesis, and routinely total cortisol in serum is measured). Urinary free cortisol is a very good screening test for hypercortisolism diagnosis. The procedure of urine collection must be carried out carefully to avoid false negative results: urine collection lasts 24 hours, and kidney function must be taken into consideration (estimated glomerular filtration rate above $30 \mathrm{ml} / \mathrm{min}$ ). UFC should be done $2-3$ times as it was proven to be poorly reproducible in mild CS (noncyclical). Repeating is not needed if the level is 3-4 times the upper normal.

Another screening test for CS is the $1 \mathrm{mg}$ ONDST, which can easily be performed in ambulatory care. In a standard procedure the patient takes $1 \mathrm{mg}$ of dexamethasone orally at 23.00 p.m., and the next day the cortisol serum concentration is measured between 8.00 and $9.00 \mathrm{a} . \mathrm{m}$. Serum cortisol below $50 \mathrm{nmol} / \mathrm{L}$ excludes CS with a sensitivity exceeding 95\% [23].

The salivary cortisol test (similarly to UFC) measures free cortisol concentration. In healthy persons with preserved circadian secretion salivary cortisol is lowest late in the evening. An advantage of this test is noninvasive sample acquisition, salivary cortisol sets enable the patient to perform the test on their own. Cortisol measurement can also be performed up to seven days after the sample was obtained (salivary cortisol is stable in room temperature for this period of time). Precise time of probe taking, saliva volume, and cortisol reference ranges depend on the test set producer. The salivary cortisol test is characterised by high sensitivity of 95-98\%; rare false negative results are observed during pregnancy or OC treatment [24, 25]. The advantages make salivary cortisol the most convenient screening test for CS diagnosis. It is surprising that it is not routinely performed in Poland.

A commonly performed procedure with dexamethasone administered at low and high doses, respectively $0.5 \mathrm{mg}$ orally every 6 hours for 2 days $(2 \mathrm{mg} / 24 \mathrm{~h} / 2$ days, DEX2) and 2 mg orally every 6 hours for the consecutive 2 days ( $8 \mathrm{mg} / 24 \mathrm{~h} / 2$ days, DEX8) is called the Liddle test. It is routinely performed during hospitalisation as the first step to confirm CS (the first two days, DEX2) and the next step is ordered for a differential diagnosis of the underlying CS cause (third and fourth day, DEX8). Lack of cortisol suppression (morning serum cortisol greater $50 \mathrm{nmol} / \mathrm{L}$, UFC above the lower reference range limit) after DEX2 confirms the CS diagnosis. Serum cortisol and UFC exceeding $50 \%$ of the basal value after DEX8 indicates extra-pituitary ACTH hypersecretion. In con- 
junction with elevated or normal ACTH levels (which occur in $30 \%$ of EAS patients) EAS diagnosis is highly probable. Simplification of the test can be realisation instead of DEX8, the $8 \mathrm{mg}$ ONDST in the same way as with the dose of $1 \mathrm{mg}$. Differential diagnosis based on the described laboratory testing has some limitations. In 10-20\% patients with ACTH secreting pituitary gland adenomas cortisol suppression after DEX8 is not present (similarly to EAS patients) [26]. On the other hand, there are EAS patients in whom the negative feedback after high dose of dexamethasone is preserved (similarly to ACTH-secreting pituitary gland adenoma cases). This is mainly observed in patients with bronchial NENs $[7,27]$. The ACTH concentration measurement is a significant laboratory problem because this hormone is a thermally unstable protein, and therefore laboratory assessment should be performed immediately after the blood sample was acquired (to limit the possibility of false negative results).

Human recombinant CRH test, as described in literature, may follow the DEX2. It can also be performed separately in order to make a diagnosis of an ACTHdependent CS. It is not a screening test. It is useful in differentiating ACTH-dependent CSs (pituitary or ectopic). In EAS patients there is no paradoxical ACTH increase due to $\mathrm{CRH}$ stimulation (ACTH increase lower than $35 \%$ to the basal value). The sensitivity of this test is assessed at $86-93 \%[28,29]$. The desmopressin test has a significance similar to that of the CRH test (V3 receptor stimulation present on the pituitary adenoma - analogically to CRH receptor, leads to an increase in ACTH), but it is less commonly used in the diagnosis of CS/EAS.

The most sensitive test differentiating between the causes of an ACTH-dependent CS is bilateral inferior petrosal sinus sampling (BIPS). Due to its invasive character BIPS is not commonly performed in Polish centres. In this procedure ACTH concentration is acquired from blood samples obtained from both inferior petrosal sinuses simultaneously. A basal ACTH ratio between IPS and peripheral vein of more than 2:1 confirms Cushing`s disease (very often ACTH rise applies only to the side corresponding to the adenoma localisation). If CRH is used for stimulation, a ratio of $>3: 1$ is considered diagnostic.

Neuroendocrine nature of ACTH producing malignancies allow for use of malignancy markers in the diagnostic work-up. The most useful are calcitonin and gastrin measurements; irrespective of the type of malignancy $[5,20,22]$. For instance, Ilias et al. reported that the calcitonin concentration was markedly raised in 28 of 40 patients $(70 \%)$ with EAS, in whom the biomarker was measured [5]. Measurement of chromogranin A or $B$ concentrations, which are markers of NENs, has not been assessed in EAS patients yet.
In the case of an EAS diagnosis made by laboratory testing, detailed visualisation studies are required. Routinely the first step is CT scanning of the neck, chest, abdomen, and pelvis. If the tumour is not apparent with this imaging technique then others are taken into consideration: MRI, somatostatin receptors scintigraphy (SRS), positron emission tomography (PET), and/or endoscopic procedures. Difficulties in CS differential diagnosis are very common. Because pituitary adenomas are statistically the most common cause of CS, EAS diagnosis can be suspected if the tumour is not visible in a pituitary MRI. This approach has limitations because in almost $40 \%$ of Cushing's disease patients the pituitary gland adenoma is not visualised (most of those tumours are microadenomas and their size can be beyond imaging sensitivity) [30]. On the other hand, not all pituitary gland tumours are hormonally secreting adenomas (this gland's incidentalomas are found in 10 to $20 \%$ of the population - data from literature are varied). Possible somatostatin receptor expression in NEN cells might make SRS according to SPECT/CT or PET/CT technique a useful diagnostic tool to localise the tumour. Unfortunately, the majority of literature cases show that SRS holds no advantages over CT or MRI for tumour visualisation and does not lead to identification of tumours different from those found in CT/MRI scans [5].

\section{Treatment}

If the EAS causing malignancy is diagnosed as a localised disease, surgery is the optimal treatment choice. Radical tumour excision may be performed in $40 \%$ of patients, and $80 \%$ of them are cured of the disease [20].

Steroidogenesis inhibitors are administered both in preparation for surgery and as palliative treatment. The drug routinely prescribed in Poland is ketoconazole (primarily registered as an antifungal drug, average dose for CS is $800-1200 \mathrm{mg}$ a day). Other drugs used in CS pharmacotherapy are aminoglutethimide, metyrapone, etomidate and mitotane. Most of these drugs need to be imported to Poland by means of a peculiar procedure or after acquiring approval for individual patients by the national health insurer (National Health Fund). Metyrapone has a short time of action and a favourable side effects profile, so it is used most commonly. Due to a narrow therapeutic range steroidogenesis inhibitors are very often prescribed along with corticosteroids in substitution doses ("block and replace" therapy).

The next therapeutic option is bilateral adrenalectomy, performed in patients without adequate response to pharmacotherapy and in cases where the cortisol level needs to be controlled for longer periods of time. 
Routinely, laparoscopic surgery is performed to avoid complications of open surgery of adrenal glands (which occur more commonly in CS patients). After bilateral adrenalectomy subsequent life-long hydrocortisone and fludrocortisone replacement is necessary.

The best treatment results and a good prognosis is observed in patients with bronchial NENs, worse in the case of thymus NENs. Patients with pancreatic NENs and medullary thyroid cancers have a bad prognosis, and the worst is that of SCLC patients. Survival is good in most cases in which the origin of malignancy is unknown, provided hypercortisolism is controlled properly [20].

\section{Case report}

The case report concerns a 68-year-old female with a history of hypertension, simple nodular goitre, past uterine myomectomy in 1986, cholecystectomy in 2006, and surgery for varicose veins of the lower limbs in 2008.

In November 2009, the patient was admitted to the Department of Internal Medicine in a local hospital in Poland. On admission, she suffered from high blood pressure ( 200/120 $\mathrm{mm} \mathrm{Hg})$, significant muscle weakness, decreased physical fitness, blurring of vision, diplopia, polydipsia, polyuria, oedema of lower extremities, and diarrhoea for the preceding three weeks. No specific cushingoid features were found in her case. Laboratory findings revealed hypokalaemia with potassium level of $2.0 \mathrm{mEq} / \mathrm{L}$ (reference range 3.5-5.0 mEq/L), possible secondary hypothyroidism, or sick euthyroid syndrome. The therapy included modification of hypotensive drugs, potassium substitution, diuretics, and L-thyroxin substitution. The explanation for the clinical symptoms and hypokalaemia was stated as diarrhoea of unknown aetiology.

In October 2010 the patient was admitted to the same ward again. Symptoms were similar to those in 2009 apart from the fact that this time she had no diarrhoea. Serum potassium level was $1.8 \mathrm{mEq} / \mathrm{L}$ (reference range 3.5-5.0 mEq/L), kaliuresis was estimated at $200 \mathrm{mEq}$ per 24 hours. (reference range $25-125 \mathrm{mEq} / 24$ hours). In an abdominal CT a left adrenal tumour was revealed, $24 \times 27 \mathrm{~mm}$ in size, with radiologic features of an adenoma. An MR scan of the pituitary gland was also performed, but it revealed no abnormalities. In the hospital discharge letter no explanation as to what was the purpose for ordering an MRI was given. Treatment included modification of hypotensive drugs, including spironolactone administration with a daily dose of $100 \mathrm{mg}$. Blood pressure was controlled properly and plasma potassium concentration increased above $4 \mathrm{mEq} / \mathrm{L}$. Suspecting the diagnosis of Conn's syndrome, the patient was referred to the Department of Endocrinology.
In February 2011, a scheduled hospitalisation of the patient took place in the Department of Endocrinology and Internal Medicine in Gdansk. There was no opportunity to discontinue drugs interfering with the renin-angiotensin-aldosterone axis, so specific laboratory tests for hyperaldosteronism were not conducted. However, the hormonal evaluation revealed a lack of circadian rhythm of serum cortisol levels and normal excretion of free urinary cortisol along with a full cortisol suppression in the overnight test with $1 \mathrm{mg}$ of dexamethasone. Taking into account the clinical course and results of additional tests, suspected Conn's syndrome diagnosis was made. Laparoscopic adrenalectomy was recommended and it was performed in April 2011, the microscopic examination confirmed an adrenal adenoma. Clinical features after surgery suggested improvement of hypertension, and no hypokalaemia was observed.

In October 2013, the patient was transferred from the Department of Internal Diseases of a local hospital in Poland to our Department with a suspicion of Cushing's syndrome. On admission, she reported a three-week history of symptoms typical of severe hypokalaemia, which were observed in the past with poor control of hypertension and easy bruising. Also, she lost her appetite and about $10 \mathrm{~kg}$ of body weight in the preceding four months despite lower limb oedema, and hoarseness of voice was noticed. On routine laboratory tests, hypernatraemia and hypokalaemia were present, and hormonal evaluation indicated an ACTH-dependent Cushing`s syndrome, probably due to ectopic ACTH secretion. What is more, dysfunction of the anterior lobe of the pituitary gland secondary to hypercortisolaemia was diagnosed. Summary laboratory results are shown in Table IV.

Given that urinary free cortisol excretion was more than four times the upper reference range value and serum ACTH was high, we decided not to perform the low- and high-dose dexamethasone suppression tests. A diagnosis of Cushing`s syndrome was made. These and other laboratory results are listed in Table V.

In order to exclude a tumour of the pituitary, an MR scan was performed, which revealed no lesion in the gland. In a chest CT scan performed as part of further diagnostic work-up, a tumour of the left lung was stated. Percutaneous needle aspiration biopsy of the tumour allowed us to make the diagnosis of a non-small cell lung cancer. Staging was assessed with a PET CT scan, which revealed neither pathological lymph nodes nor distant metastases. The patient was qualified for thoracic surgery. On November 2013, after pre-treatment with ketoconazole, administering hydrocortisone prophylaxis, left pneumonectomy and lymphadenectomy were performed. Based on the 
Table IV. Laboratory results before lung lobectomy. ONDSTovernight dexamethasone suppression test

\begin{tabular}{lcc}
\hline Assay & Result & Reference range \\
\hline ACTH 8 am [pg/mL] & 282 & $<46$ \\
\hline Serum cortisol 8 a.m. [nmol/L] & 816 & $101-536$ \\
\hline Serum cortisol 8 p.m. [nmol/L] & 780 & $79-478$ \\
\hline Urinary free cortisol [nmol/ 24hr] & 10420 & $12-486$ \\
\hline Serum cortisol after 8 mg 0NDST & 725 & For interpretation \\
\hline DHEA-S [ug/dL] & 128 & $17-90$ \\
\hline Androstendione [ng/mL] & 10 & $0.3-3.5$ \\
\hline Testosterone [nmol/L] & 4.57 & $0.38-1.97$ \\
\hline TSH [uU/mL] & 0.182 & $0.34-4.94$ \\
\hline $\mathrm{fT}{ }_{4}[\mathrm{pmol} / \mathrm{L}]$ & 8.88 & $9.01-19.05$ \\
\hline $\mathrm{fT}{ }_{3}[\mathrm{pmol} / \mathrm{L}]$ & 3.38 & $2.63-5.70$ \\
\hline $\mathrm{FSH}[\mathrm{IU} / \mathrm{L}]$ & 0.71 & $2,58-150,53$ \\
\hline $\mathrm{PRL}[\mathrm{mU} / \mathrm{L}]$ & 266.91 & $108.8-557.1$ \\
\hline $\mathrm{IGF}-1[\mathrm{ng} / \mathrm{mL}]$ & 77.90 & $29-204$ \\
\hline
\end{tabular}

Table V. Laboratory results before lung lobectomy

\begin{tabular}{lcc}
\hline Assay & Result & Reference range \\
\hline CEA $[\mathrm{ng} / \mathrm{mL}]$ & 6.36 & $<5$ \\
\hline CA $125[\mathrm{U} / \mathrm{mL}]$ & 30 & $<35$ \\
\hline CA19.9 $[\mathrm{U} / \mathrm{mL}]$ & 55.4 & $<37$ \\
\hline AFP $[\mathrm{IU} / \mathrm{mL}]$ & 6.76 & $<11.6$ \\
\hline CgA $[\mathrm{ng} / \mathrm{mL}]$ & 120.8 & $<100$ \\
\hline Calcitonin $[\mathrm{pg} / \mathrm{mL}]$ & $<2.0$ & $<11.5$ \\
\hline
\end{tabular}

histopathological report a final diagnosis of a tubular mucus-secreting adenocarcinoma of the lung was established. Because of lymph node involvement and pulmonary artery invasion, the stage was classified as pT4N1Mx. Immunohistochemical staining for ACTH of the cancer tissue was negative. The post-operative period was complicated with a bacterial pneumonia. Regular laboratory testing following the surgery suggested persisting ACTH-dependent hypercortisolaemia, despite discontinuation of hydrocortisone administration. After successful antibiotic therapy for pneumonia we conducted a two-day suppression test with a daily 2-mg dose of dexamethasone (DEX2), the result of which was complete suppression of cortisol secretion $(<50 \mathrm{nmol} / \mathrm{L})$. Other laboratory results are shown in Table VI.

In April 2014, the patient was admitted the Oncology Department for palliative radiotherapy of bone metastases of the left femur region.
Table VI. Laboratory results after lung lobectomy. DEX2-serum cortisol 8 am after $2 \mathrm{mg} / 24 \mathrm{hr} / 2$ days of dexamethasone

\begin{tabular}{lcc}
\hline Assay & Result & Referral range \\
\hline ACTH $8 \mathrm{am}[\mathrm{pg} / \mathrm{mL}]$ & 10 & $<46$ \\
\hline Serum cortisol $8 \mathrm{am} \mathrm{[nmol} / \mathrm{L}]$ & 605 & $101-536$ \\
\hline Serum cortisol $8 \mathrm{pm}[\mathrm{nmol} / \mathrm{L}]$ & 405 & $79-478$ \\
\hline Urine free cortisol [nmol/L] & 394 & $12-486$ \\
\hline DEX2 [nmol/L] & $<28$ & For interpretation \\
\hline DHEA-s [ug/dL] & 15 & $17-90$ \\
\hline Androstenedione [ng/mL] & 10 & $0.3-3.5$ \\
\hline Testosterone $[\mathrm{nmol} / \mathrm{L}]$ & 4.57 & $0.38-1.97$ \\
\hline TSH [uU/mL] & 2.79 & $0.34-4.94$ \\
\hline fT $[\mathrm{pmol} / \mathrm{L}]$ & 13.87 & $9.01-19.05$ \\
\hline $\mathrm{fT}{ }_{3}[\mathrm{pmol} / \mathrm{L}]$ & 4.09 & $2.63-5.70$ \\
\hline FSH [IU/L] & 1.30 & $2.58-150.53$ \\
\hline PRL [mU/L] & 266.91 & $108.8-557.1$ \\
\hline IGF-1 [ng/mL] & 193.3 & $29-304$ \\
\hline
\end{tabular}

\section{Discussion}

This case raises a number of clinical questions, the most important of which are the following: does this case feature a cyclical Cushing's syndrome? Could the progression of the diagnosed lung cancer have been so slow? Why was there no hypocortisolism in the postoperative period that is typical for cured patients with Cushing's syndrome (hormonal replacement therapy was not necessary)? Taking into consideration the fact that the patient was hospitalised a few times in the past due to almost identical symptoms associated with severe hypokalaemia, could the diagnosis of CS or cancer have been made earlier? And consequently, would the diagnosis of cyclical Cushing's syndrome have been probable? Doubts remain, however, with such a diagnosis, i.e. ectopic ACTH secretion due to one of the most aggressive malignancies: lung cancer. An alternative diagnosis is the concomitance of two rare endocrinopathies: Conn's and Cushing's syndromes. A possible explanation for the lack of hypercortisolaemia after surgery was performed is a typical reaction present in healthy individuals, which results from perioperative stress, and additionally infection in our case. In Cushing's syndrome patients cured by surgical treatment, glucocorticoid replacement therapy must be administered for several months after surgery, and sometimes it is impossible to discontinue this treatment. Her normal postoperative cortisol could be related to small bone metastatic lesions, especially because subsequently she presented with bone metastases. 


\section{Conclusions}

Cushing syndrome due to EAS is a diagnosis requiring the appropriate medical diagnostic approach, based on properly taken history, a detailed physical examination, ordering diagnostic procedures, and finally treatment. Ectopic ACTH secretion is an extraordinary clinical challenge, and so there are a lot of patients with unknown origin of the disease in spite of detailed diagnostic workup. Due to multiple complications of hypercortisolism, like severe infections, DVT, and PE, which are the main causes of death of those patients, proper diagnosis and treatment should be administered as soon as possible. In summary, a clinical suspicion of CS must be initially verified with one or more screening tests, which are used in ambulatory care. In doubtful cases or positive results of screening tests, patients must be sent to specialised clinics for a diagnostic and treatment process of CS.

\section{References}

1. Milewicz A. Endokrynologia Kliniczna. Polskie Towarzystwo Endokrynologiczne. Wrocław 2012; II: 375.

2. Lindholm J, Juul S, Jorgensen JO et al. Incidence and late prognosis of Cushing's syndrome: a population-based study. J Clin Endocrinol Metab 2001; 86: 117-123. DOI: jcem.86.1.7093.

3. Brown WH. A case of pluriglandular syndrome: diabetes of bearded women. Lancet 1928; 1022-1023. DOI: 10.1016/s0140-6736(00)84800-x.

4. Liddle GW, Island DP, Ney RL et al. Nonpituitary neoplasms and Cushing's syndrome. Ectopic "adrenocorticotropin" produced by nonpituitary neoplasms as a cause of Cushing's syndrome. Arch Intern Med 1963; 111: 471-475. DOI: 10.1001/archinte.1963.03620280071011.

5. Ilias I, Torpy DJ, Pacak K et al. Cushing's Syndrome Due to Ectopic Corticotropin Secretion: Twenty Years' Experience at the National Institutes of Health. J Clin Endocrinol Metab. 2005; 90: 4955-4962. DOI: 10.1210/jc.2004-2527.

6. Witek P, Witek J, Zieliński G et al. Ectopic Cushing's syndrome in light of modern diagnostic techniques and treatment options. Neuroendocrinology Letters 2015; 36: 201-208.

7. Ejaz S, Vassilopoulou-Sellin R, Busaidy NL et al. Cushing syndrome secondary to ectopic adrenocorticotropic hormone secretion. Cancer 2011; 117: 4381-4389. DOI: 10.1002/CNCR.26029.

8. Newell-Price J, Bertagna X, Grossman AB et al. Cushing's syndrome. The Lancet 2006; 367: 1605-1617. DOI: 10.1016/S0140-6736(06)68699-6.

9. Juszczak A, Grossman A. The management of Cushing's disease- from investigation to treatment. Endokrynol Pol 2013; 64: 166-174.

10. Dworakowska D, Drabarek A, Wenzel I et al. Adrenocortical cancer (ACC) - literature overviev and own experience. Endokrynol Pol 2014; 65: 492-512. DOI: 10.5603/EP.2014.0069.

11. Kamp K, Alwani RA, Korpershoek E et al. Prevalence and clinical features of the ectopic ACTH syndrome in patients with gastroenteropancreatic and thoracic neuroendocrine tumors. Eur J Endocrinol 2015; 174: 271-280. DOI: 10.1530/EJE-15-0968.

12. Tsirona S, Tzanela $M$, Botoula $E$ et al. Clinical presentation and long- term outcome of patiens with ACTH syndrome due to bronchial carcinoid tumors: a one- center experience. Endocrine Practice 2015; 1: 11041-1110. DOI: 10.4158/ep15647.or.

13. Ghazi AA, Dezfooli AA, Amirbaigloo A et al. Ectopic Cushing`s syndrome secondary to lung and mediastinal tumours- report from a tertiary care centre in Iran. Endokrynol Pol 2015; 66: 2-9. DOI: 10.5603/EP.2015. 0002 .

14. Venugopal H, Griffin K, Amer S. A case of severe ectopic ACTH syndrome from an occult primary - diagnostic and management dilemmas. Endocrinol Diabetes Metab Case Rep 2015; 2015: 150099. DOI: 10.1530/ EDM-15-0099.

15. Kunc M, Gabrych A, Czapiewski P et al. Paraneoplastics syndromes in olfactory neuroblastoma. Contemporary Oncology 2015; 19: 6-16. DOI: $10.5114 /$ wo.2015.46283.

16. Isidori AM, Lenzi A. Ectopic ACTH syndrome. Arq Bras Endocrinol Metab. 2007; 51: 1217-1225. DOI: 10.1590/S0004-27302007000800007.

17. Sworczak K, Blaut K, Malecha M et al. Ectopic ACTH syndrome associated with ovarian steroid- cell tumor. J Endocrinol Invest 2002; 369-372. DOI: 10.1007/BF03344020.

18. Swiatkowska-Stodulska R, Sworczak K. Disorders of hemostasis in overt and subclinical hypercortisolism. Exp Clin Endocrinol Diabetes 2013; 121: 588-594. DOI: $10.1055 / \mathrm{s}-0033-1355385$.

19. Beuschlein F, Hammer GD. Ectopic pro-opiomelanocortin syndrome. Endocrinol Metab Clin North Am 2002; 31: 191-234. DOI: 10.1016/ S0889-8529(01)00025-1.

20. Isidori AM, Kaltsas GA, Pozza C et al. The Ectopic Adrenocorticotropin Syndrome: clinical features, diagnosis, managment and long-term follow- up. J Clin Endocrinol Metab 2006; 91: 371-377. DOI: 10.1210/ jc.2005-1542.

21. Sarlis NJ, Chanock SJ, Nieman LK. Cortisolemic indices predict severe infections in Cushing syndrome due to ectopic production of adrenocorticotropin. J Clin Endocrinol Metab 2000; 85: 42-47. DOI: 10.1210/ jcem.85.1.6294

22. Howlett TA, Drury PL, Perry L et al. Diagnosis and management of ACTH-dependent Cushing's syndrome: comparison of the features in ectopic and pituitary ACTH production. Clin Endocrinol (Oxf) 1986; 24: 699-713. DOI: 11.1111/j.1365-2265.1986.tb01667.x.

23. Wood PJ, Barth JH, Freedman DB et al. Evidence for the low dose dexamethasone suppression test to screen for Cushing syndrome: recommendations for a protocol for biochemistry laboratories. Ann Clin Biochem 1997; 34: 222-229. DOI: 10.1177/000456329703400302.

24. Trilck M, Flitsch J, Ludecke DK et al. Salivary cortisol measurement - a reliable method for the diagnosis of Cushing's syndrome. Exp Clin Endocrinol Diabetes 2005; 113: 225-30. DOI: 10.1055/s-2005-837667.

25. Putignano P, Toja P, Dubini A et al. Midnight salivary cortisol versus urinary free and midnight serum cortisol as screening tests for Cushing's syndrome. J Clin Endocrinol Metab 2003; 88: 4153-4157. DOI: 10.1210/jc.2003-030312.

26. Arnaldi G, Angeli A, Atkinson AB et al. Diagnosis and complications of Cushing's syndrome: a consensus statement. J Clin Endocrinol Metab 2003; 88: 5593-5602. DOI: 10.1210/jc.2003-030871.

27. Kolesnikova G, Lapshina A, Voronkova I et al. Comparative Analysis of Clinical, Hormonal and Morphological Studies in Patients with Neuroendocrine ACTH-Producing Tumours. Inter J Endocrinol 2013; 2013: 659232. DOI: $10.1155 / 2013 / 659232$.

28. Reimondo G, Paccotti P, Minetto M et al. The corticotrophin releasing hormone test is the most reliable noninvasive method to differentiate pituitary from ectopic ACTH secretion in Cushing's syndrome. Clin Endocrinol (Oxf) 2003; 58: 718-724. DOI: 10.1046/j.1365-2265.2003.01776.x.

29. Nieman LK, Oldfield EH, Wesley R et al. A simplified morning ovine corticotropin-releasing hormone stimulation test for the differential diagnosis of adrenocorticotropin-dependent Cushing's syndrome. J Clin Endocrinol Metab 1993; 77: 1308-1312. DOI: 10.1210/jcem.77.5.8077325.

30. Invitti C, Pecori Giraldi F, de Martin M et al. Diagnosis and management of Cushing's syndrome: results of an Italian multicentre study. Study Group of the Italian Society of Endocrinology on the Pathophysiology of the Hypothalamic-Pituitary-Adrenal Axis. J Clin Endocrinol Metab 1999; 84: 440-448. DOI: 10.1210/jcem.84.2.5465. 


\section{Polish version}

\section{Wstęp}

Zespół objawów klinicznych, zarówno podmiotowych, jak i przedmiotowych, które wynikają z hiperkortyzolemii określa się mianem zespołu Cushinga (CS, Cushing syndrome). Nadmiar kortyzolu w organizmie może mieć źródło egzo- lub endogenne. Powszechnie uważa się, że najczęstszą przyczyną CS jest terapia glikokortykosteroidem w dawkach farmakologicznych, większych niż substytucyjne, z powodu różnych chorób, na przykład tkanki łącznej [1]. Ocena kliniczna, diagnostyka oraz leczenie chorych z endogennym CS stanowi duży problem endokrynologiczny. Szacuje się, że zachorowalność na ten rzadki zespół wynosi 2,5 przypadka/milion mieszkańców/rok [2]. Jedną z możliwych przyczyn CS jest ektopowe, czyli poza przysadkowe wydzielanie ACTH, przez nowotwór łagodny lub złośliwy. Pierwsze opisy CS w przebiegu poza przysadkowych guzów wydzielających ACTH pochodzą z 1928 roku [3]. Pojęcie zespołu ektopowego wydzielania ACTH (EAS, ectopic ACTH secretion) zostało zaproponowane pierwszy raz przez Liddla w 1963 roku, głównie w odniesieniu do chorych z drobnokomórkowym rakiem płuc (SCLC, small cell lung cancer) [4]. Od tego czasu etiologia EAS uległa istotnej zmianie, poza SCLC opisano inne nowotwory, których częstość znacząco wzrosła [5-7].

\section{Epidemiologia}

Najczęstszą przyczyną CS jest jego postać ACTH-zależna pochodzenia przysadkowego, określana mianem choroby Cushinga, której częstość szacuje się na 70\%. Ektopowe wydzielanie ACTH stanowi $10 \%$ chorych z CS, a inne przyczyny CS podsumowano w tabeli I [8-10]. Typowo choroba Cushinga dominuje u kobiet, natomiast CS w przebiegu EAS $\mathrm{w}$ równym stopniu lub częściej dotyczy mężczyzn. Wiek zachorowania na chorobę Cushinga waha się w granicach 30-40 lat, EAS najczęściej stwierdza się u chorych w wieku 45-50 lat.

Tabela I. Przyczyny zespotu Cushinga

\begin{tabular}{ll}
\hline Zespół Cushinga ACTH-zależny & \\
\hline Choroba Cushinga & $70 \%$ \\
\hline Ektopowe wydzielanie ACTH & $10 \%$ \\
\hline Postać nieokreślona & $5 \%$ \\
\hline Zespół Cushinga ACTH-niezależny & \\
\hline Gruczolak kory nadnerczy & $10 \%$ \\
\hline Rak kory nadnerczy & $5 \%$ \\
\hline Inne & $\sim 2 \%$ \\
\hline
\end{tabular}

Tabela II. Przyczyny ektopowego wydzielania ACTH

\begin{tabular}{lll}
\hline \multicolumn{2}{l}{ Przyczyny ektopowego wydzielania ACTH } & \\
\hline Częste & Rzadkie & Bardzo rzadkie \\
\hline NEN oskrzela & Rak jajnika & Rak przetyku \\
\hline Rak płuca & Rak jelita grubego & Guz nerki \\
\hline NEN grasicy & Rak prostaty & $\begin{array}{l}\text { Rak wątrobowo- } \\
\text { komórkowy }\end{array}$ \\
\hline $\begin{array}{lll}\text { NEN trzustki/ przewodu } \\
\text { pokarmowego }\end{array}$ & Rak szyjki macicy & Rak piersi \\
\hline Rak rdzeniasty tarczycy & Neuroblastoma & Guz ślinianki \\
\hline Guz chromochtonny & & Międzybłoniak \\
nadnerczy & & opłucnej \\
\hline & & Chłoniaki \\
\hline & Czerniak \\
\hline & Guzy jąder \\
\hline & Rak krtani \\
\hline
\end{tabular}

NEN — nowotwór neuroendokrynny

Większość guzów wydzielających ACTH ma charakter złośliwy, wywodzi się z linii komórek zdolnych do wychwytu amin i dekarboksylacji (APUD, amine precursor uptake and descarboxylation), aktualnie określanych jako komórki rozproszonego układu neuroendokrynnego (DES, diffuse endocrine system), tworząc w istocie nowotwór neuroendokrynny (NEN, neuroendocrine neoplasm). Ze względu na różnice w klasyfikacji, lepsze możliwości diagnostyczne, na przestrzeni ostatnich dekad coraz mniejszą grupę chorych z EAS stanowią chorzy z SCLS. Do najczęstszych przyczyn EAS należy: NEN oskrzeli (25\%), raka płuc (20\%), NEN grasicy $(11 \%)$, NEN trzustki (8\%), rak rdzeniasty tarczycy (6\%), guz chromochłonny nadnerczy $(5 \%)$, a nowotwory wywodzące się z innych narządów niż gruczoły dokrewne i płuca stanowią 6-8\% [7, 8, 11]. Dodatkowo dużą grupę stanowią pacjenci z nieznanym punktem wyjścia choroby nowotworowej, których odsetek w zależności od piśmiennictwa ocenia się na $20 \%$ przypadków (najczęściej ostateczne rozpoznanie to NEN oskrzeli) $[5,12,13]$. Wszystkie możliwe przyczyny EAS przedstawiono w tabeli II $[6,7,11,14-17]$.

\section{Symptomatologia}

Symptomatologia CS w przebiegu EAS najczęściej odpowiada objawom spotykanym u chorych na CS wywołanego inną przyczyną, determinowana jest przez czas trwania i poziom hiperkortyzolemi, osobniczą 
Tabela III. Najczęstsze objawy zespotu Cushinga

\begin{tabular}{ll}
\hline Objaw & $\begin{array}{c}\text { Częstotliwość } \\
\text { występowania (\%) }\end{array}$ \\
\hline Otyłość/przyrost masy ciała & 95 \\
\hline Twarz plethoryczna & 90 \\
\hline Twarz księżycowata & 90 \\
\hline Obniżenie libido & 90 \\
\hline Cienka skóra & 85 \\
\hline Zaburzenia miesiączkowania & 80 \\
\hline Nadciśnienie tętnicze & 75 \\
\hline Hirsutyzm & 75 \\
\hline Zaburzenia psychiczne & 70 \\
\hline Łatwe siniaczenie się & 65 \\
\hline Stany przed/cukrzycowe & 60 \\
\hline Ostabienie & 60 \\
\hline Osteoporoza/złamania niskoenergetyczne & 50 \\
\hline Kamica moczowa & 50 \\
\hline
\end{tabular}

wrażliwość na glikokortykosteroidy oraz zaawansowanie choroby nowotworowej. Najczęstsze objawy CS przedstawiono w tabeli III [8].

Ponadto można wymienić: kark bawoli, poduszeczki tłuszczowe w okolicy nadobojczykowej, wytrzeszcz, głębokie/szerokie rozstępy koloru fioletowego, trudne gojenie się ran, przewlekłe infekcje skóry na przykład: grzybicze, zmiany łojotokowe/ trądzikowe, zaniki mięśniowe, obrzęki kończyn dolnych, powikłania żylno-zakrzepowe [1,18]. Ze względu na często szybką progresję nowotworu złośliwego będącego przyczyną EAS oraz wysokie stężenia ACTH i wystymulowanego kortyzolu, można oczekiwać nieco odmiennego obrazu klinicznego. Z możliwych różnic w przebiegu EAS należy wymienić: krótki wywiad, melanodermię, spadek/brak przyrostu masy ciała, brak typowego rozmieszczenia tkanki tłuszczowej, głęboką hipokaliemię, częstsze/poważniejsze infekcje oraz zaburzenia psychiatryczne [7, 19-22]. W przypadku chorych na SCLS lub inne nowotwory o dużej złośliwości, dominują z reguły objawy ogólne, miejscowe lub odległe (przerzuty) choroby nowotworowej oraz ciężka hipokaliemia. Należy podkreślić, że nie ma swoistych objawów różnicujących poszczególne przyczyny CS, dlatego podstawą rozpoznania jest przeprowadzenie dalszej szczegółowej diagnostyki.

\section{Diagnostyka}

Podejrzenie kliniczne CS, wymaga weryfikacji laboratoryjnej. W pierwszej kolejności należy potwierdzić hiperkortyzolemię, następnie zróżnicować na postać
ACTH-zależną i ACTH-niezależną, w przypadku oznaczalnego/podwyższonego ACTH (brak ujemnego sprzężenia zwrotnego) przeprowadzić diagnostykę w kierunku choroby Cushinga lub EAS [6, 8]. W praktyce ten oczywisty schemat diagnostyczny wiąże się z szeregiem wyzwań, które stają przed klinicystą. Nie ma swoistego, pojedynczego badania, które by potwierdziło CS, dlatego należy posiłkować się szeregiem testów. Połączenie wielu badań laboratoryjnych, w tym inwazyjnych, sprawia, że czułość rozpoznania EAS sięgnąć może 100\%, przy swoistości 98\% [20]. Nierzadko hiperkortyzolemia nie jest konsekwencją CS i występować może w depresji, alkoholizmie, jadłowstręcie psychicznym, ciąży (rzekomy CS), być naturalną konsekwencją infekcji czy sytuacji stresowych oraz mieć charakter polekowy, na przykład doustna tabletka antykoncepcyjna. Trudności mogą też wynikać z okresowego podwyższenia kortyzolu u pacjentów z tak zwanym cyklicznym CS, u których diagnostyka laboratoryjna może nie odbiegać od normy w okresie braku hipersekrecji kortyzolu. Największy problem mogą stanowić guzy wydzielające ACTH, zarówno przysadkowe, a w szczególności poza przysadkowe, których wielkość jest poniżej czułości diagnostycznej stosowanych badań obrazowych. Za najbardziej pewne rozpoznanie EAS należałoby uznać ustąpienie objawów klinicznych CS po resekcji guza oraz dodatnie barwienia immunohistochemicznego na obecność ACTH lub prekursorów (POMC) w preparatach patomorfologicznych. Ma to również swoje ograniczenia, między innymi guzy nieoperacyjne (brak możliwości wyleczenia) oraz heterogenność populacji komórek nowotworowych (fałszywie ujemne barwienia na ACTH) [14].

Do badań mających znaczenie $\mathrm{w}$ diagnostyce CS należy wymienić: dobowe wydalanie wolnego kortyzolu w moczu, test nocny z $1 \mathrm{mg}$ deksametazonu, oznaczenie wieczornego stężenia kortyzolu w ślinie, ocena rytmu wydzielania kortyzolu (stężenie kortyzolu w surowicy w godzinach porannych i wieczornych), test hamowania małą/dużą dawką deksametazonu, test z CRH lub desmopresyną, czy niewykonywane w Polsce oznaczenia próbek krwi z zatok skalistych dolnych (BIPS, bilateral inferior petrosal sinus sampling). Za najbardziej przydatne badania przesiewowe należy uznać test hamowania z $1 \mathrm{mg}$ deksametazonu, wieczorne oznaczenie kortyzolu $\mathrm{w}$ ślinie oraz wydalanie wolnego kortyzolu w dobowej zbiórce moczu (co najmniej 2 zbiórki). Test z CRH oraz BIPS stanowią ważne badania w diagnostyce różnicowej CS.

Kortyzol w moczu stanowi frakcję wolną (niezwiązaną z białkami) kortyzolu w organizmie, podwyższone wydalanie występuje zarówno w CS, jaki i rzekomym CS, natomiast DTA w niewielkim stopniu wpływa na to oznaczenie (np. duża ilość 
białka wiążącego glikokortykosteroidy stymulowana przez DTA daje wyniki fałszywie dodatnie w przypadku oznaczenia kortyzolu w surowicy, rutynowo oznaczany jest całkowity kortyzol). Wolny kortyzol w moczu stanowi dobre pojedyncze badanie przesiewowe w kierunku hiperkortyzolemii. Celem uniknięcia wyniku fałszywie ujemnego należy przestrzegać zasad zbierania moczu (zbiórka 24-godzinna), uwzględnić wielkość filtracji kłębuszkowej ([GFR, glomerular filtration rate] $>30 \mathrm{ml} / \mathrm{min}$ ) oraz w przypadkach wątpliwych badanie powtórzyć 2-3-krotnie (cykliczny CS) [12]. Gdy wynik 3-4-krotnie przekracza górną granicę normy, powtórzenie badania nie jest wymagane, z dużym prawdopodobieństwem wskazuje na CS.

Kolejnym badaniem przesiewowym jest test hamowania z $1 \mathrm{mg}$ deksametazonu, szczególnie polecany do przeprowadzenia $w$ warunkach ambulatoryjnych. Zasada testu polega na podaniu o godzinie 23.00 doustnie $1 \mathrm{mg}$ deksametazonu oraz oznaczeniu kortyzolu $\mathrm{w}$ surowicy kolejnego dnia $\mathrm{w}$ godzinach porannych 8.00-9.00. Za punkt odcięcia, wykluczający CS przyjęto stężenie kortyzolu poniżej $50 \mathrm{nmol} / \mathrm{l}$, czułość badania oceniana jest na $>95 \%$ [23].

Oznaczenie stężenia kortyzolu w ślinie podobnie jak kortyzolu w moczu, jest pomiarem frakcji wolnej kortyzolu. U osób zdrowych, z zachowanym rytmem wydzielania kortyzolu, jego stężenie $\mathrm{w}$ godzinach późno wieczornych jest niskie. Zaletą oznaczenia kortyzolu w ślinie poza rzadszymi wynikami fałszywie dodatnimi (doustna tabletka antykoncepcyjna, ciąża), jest nieinwazyjne pobranie materiału. Dodatkowo zestawy do pobierania śliny, umożliwiają jej samodzielne pobranie oraz wykonanie oznaczenia do $7 \mathrm{dni}$ od zabezpieczenia materiału (kortyzol zachowuje stabilność w temperaturze pokojowej przez podany okres). Dokładny czas pobrania/ilość materiału oraz zakres wartości referencyjnych zależy od zestawu/ /producenta testu. Badanie cechuje się wysoką czułością w zakresie 95-98\% [24, 25]. Wszystkie powyższe cechy sprawiają, że oznaczenie kortyzolu w ślinie wydaje się być najlepszym testem przesiewowym w kierunku CS, dlatego dziwi fakt braku szerokiego rozpowszechnienia tego narzędzia diagnostycznego w Polsce.

Powszechnie wykonywany test hamowania mała/ /dużą dawką deksametazonu, w schemacie $0,5 \mathrm{mg}$ p.o. co 6 godzin przez dwa dni $(2 \mathrm{mg} / \mathrm{d} . / 2 \mathrm{dni}$, DEX2), a następnie $2 \mathrm{mg}$ p.o. co 6 godzin przez dwa dni $(8 \mathrm{mg} / \mathrm{d} . / 2 \mathrm{dni}, \mathrm{DEX} 8)$ określany jest mianem testu Liddle'a. Badanie to, wykonywane w warunkach szpitalnych jest testem potwierdzającym CS (pierwsze dwa dni, DEX2) oraz różnicującym (trzeci i czwarty dzień, DEX8). Brak hamowania wydzielania kortyzolu (kortyzol poranny w surowicy $>50 \mathrm{nmol} / \mathrm{l}$, wolny kortyzol w dobowej zbiórce moczu powyżej progu oznaczalności) z DEX2, stanowi podstawę rozpoznania CS. Brak spadku stężenia kortyzolu w surowicy oraz dobowego wydalania wolnego kortyzolu w moczu o > 50\% względem wartości wyjściowej (przed rozpoczęciem testu) z DEX8, wskazuje na poza przysadkową postać CS. W łączności z oznaczalnym (mieszczącym się w granicach wartości referencyjnych, 1/3 przypadków EAS ma prawidłowe ACTH) lub podwyższonym stężeniem ACTH w surowicy, sugeruje rozpoznanie CS w przebiegu EAS. Uproszczeniem tego testu może być wykonanie zamiast 2-dniowego DEX8, nocnego testu hamowania z $8 \mathrm{mg}$, podobnie jak w przypadku z dawką $1 \mathrm{mg}$. Proste zróżnicowanie chorych oparte na opisie badania ma swoje ograniczenia. $\mathrm{W}$ grupie chorych z przysadkowym CS szacowanej na 10-20\% przypadków, stwierdza się, podobnie jak u pacjentów z EAS brak hamowania po dużej dawce deksametazonu [26]. $Z$ drugiej strony opisano hiperkortyzolemię u chorych z EAS, gdzie zachowane było ujemne sprzężenie zwrotne po zastosowaniu dużej dawki deksametazonu, podobnie jak w postaci przysadkowej CS, głównie u chorych z NEN oskrzeli [7, 27]. Problem dotyczy również oznaczenia ACTH. Jest to białko niestabilne termicznie, $z$ tego względu analiza laboratoryjna powinna być wykonana natychmiast po pobraniu próbki krwi (możliwość uzyskania wyniku fałszywie ujemnego).

Test z ludzkim rekombinowanym CRH w zależności od publikacji może być wykonywany po dwóch dniach hamowania z małą dawką deksametazonu $(2 \mathrm{mg} / \mathrm{d}$.) lub niezależnie po potwierdzeniu ACTH-zależnego CS. Rola testu polega na zróżnicowaniu ACTH-zależnego CS na postać przysadkową i pozaprzysadkową. Nie jest to test przesiewowy, potwierdzający sam CS. U pacjenta z EAS, nie dochodzi do paradoksalnego wzrostu ACTH po podaniu CRH (wzrost ACTH $<35 \%$ względem wartości wyjściowej). Czułość badania określa się na 86-93\% [28, 29]. Znaczenie testu z desmopresyną jest podobne jak testu z CRH (receptor V3 obecny w gruczolaku, podobnie jak pobudzenie receptora dla CRH powoduje wzrost $\mathrm{ACTH}$ ), lecz jego rozpowszechnienie $\mathrm{w}$ diagnostyce CS/EAS jest mniejsze.

Za najczulsze badanie różnicujące ACTH-zależny CS uważa się badanie BIPS. Ze względu na inwazyjny charakter, BIPS praktycznie nie jest wykonywane w Polsce. Idea badania polega na pobraniu próbek krwi z obu zatok skalistych dolnych i oceny stężenia ACTH. Gradient ACTH między próbkami krwi z zatok skalistych a krwią obwodową przekraczający 2:1 w większości przypadków wskazuje na chorobę $\mathrm{Cu}$ shinga, tym samym wyklucza rozpoznanie EAS. Czułość badania można dodatkowo zwiększyć, kojarząc go z podaniem $\mathrm{CRH}$ (gradient $>$ 3:1 potwierdza diagnozę). Brak możliwości wykonania BIPS istotnie pogarsza czułość i swoistość rozpoznania CS w przebiegu EAS. 
Neuroendokrynny charakter większości nowotworów przebiegających z EAS daje możliwość poszerzenia diagnostyki o markery nowotworowe. Za najbardziej przydatne uważa się oznaczenie kalcytoniny oraz gastryny, niezależnie od typu nowotworu [5, 20, 22]. Dla przykładu, w jednej z analiz stężenie kalcytoniny było podwyższone u 28 z 40 chorych z EAS (70\%), u których oznaczono stężenie powyższego biomarkera [5]. Znaczenie innego czułego markera NEN w surowicy jak chromogranina A i B nie zostało dotychczas zbadane u chorych z EAS.

W przypadku potwierdzenia laboratoryjnego EAS chory wymaga dokładnej diagnostyki obrazowej. $Z$ reguły $w$ początkowym okresie oparta jest ona na badaniu tomografii komputerowej (CT, computed tomography) szyi, klatki piersiowej, brzucha czy miednicy mniejszej. W przypadku nieuwidocznienia guza do rozważenia pozostają inne narzędzia diagnostyczne, takie jak: rezonans magnetyczny (MRI, magnetic resosnanse imaging), scyntygrafia receptorów dla somatostatyny (SRS, somatostin receptor scintigraphy), pozytonowa tomografia emisyjna (PET, positron emission tomography) czy badania endoskopowe. Ze względu na częste trudności w laboratoryjnej diagnostyce różnicowej poszczególnych przyczyn CS oraz dominującą etiologię przysadkowej postaci CS, rozpoznanie EAS można by postawić, wykluczając zmianę ogniskową w badaniu MRI głowy celowanym na przysadkę. Postępowanie to ma również swoje ograniczenia, bowiem nawet u $40 \%$ pacjentów z chorobą Cushinga nie udaje się uwidocznić zmiany ogniskowej w przysadce (wielkość poniżej czułości metody, większość zmian ma charakter mikrogruczolaka) [30]. Z drugiej strony stwierdzenie zmiany w przysadce nie musi oznaczać hormonalnie czynnego gruczolaka, ze względu na duże rozpowszechnienie zmian o charakterze incydentaloma, sięgające 10-20\% populacji ogólnej (dane $\mathrm{z}$ piśmiennictwa są bardzo zróżnicowane). Możliwa ekspresja receptorów dla somatostatyny w przypadku NEN wskazywałaby na duże możliwości SRS jako badania lokalizującego guz. Niestety, większość prac jednoznacznie wskazuje na brak przewagi tego badania nad CT/MRI, między innymi nie pozwala na identyfikację nowych ognisk niż te znalezione w CT/MRI [5].

\section{Leczenie}

W przypadku lokalizacji ogniska pierwotnego leczenie operacyjne jest postępowaniem optymalnym. Radykalne leczenie można zastosować u $40 \%$ chorych, z czego do $80 \%$ udaje się wyleczyć [20].

$\mathrm{W}$ ramach przygotowania do leczenia operacyjnego oraz w przypadku postępowania paliatywnego, leczenie polega na zastosowaniu inhibitorów steroido- genzy. Do leków powszechnie stosowanych w polskich warunkach należy ketokonazol (pierwotnie zarejestrowany jako lek przeciwgrzybiczy, stosowane dawki w CS 800-1200 mg/d.). Z innych leków należy wymienić aminoglutetymid, metyrapon, etomidat oraz mitotan. Wymienione leki w większości zamawiane są w ramach importu docelowego lub wymagają indywidualnej zgody płatnika (Narodowy Fundusz Zdrowia) na leczenie w przypadku refundacji. Metyrapon, ze względu na szybki początek działania oraz profil bezpieczeństwa, aktualnie jest lekiem najczęściej stosowanym na świecie. Ze względu na wąski zakres terapeutyczny, leki te dość często stosuje się w skojarzeniu z glikokortykosteroidami w dawce substytucyjnej (zablokuj i zastąp).

Inną możliwością leczenia hiperkortyzolemii jest obustronna adrenalektomia, polecana szczególnie w przypadku braku adekwatnej skuteczności leczenia farmakologicznego oraz konieczności kontroli kortyzolemii przez dłuższy okres czasu. Aktualnie takie leczenie można wykonać metodą laparoskopową, co w dużym stopniu redukuje możliwe powikłania „klasycznej" adrenalektomi, które u chorych na CS występować mogą szczególnie często. Wykonanie powyższej procedury wymaga długotrwalego leczenia substytucyjnego preparatami hydrokortyzonu i fludrokortyzonu.

Najlepsze wyniki leczenia oraz dobre prognozy uzyskuje się $u$ chorych z NEN oskrzeli, pośrednie u chorych z NEN grasicy, złe w przypadku NEN trzustki i raka rdzeniastego tarczycy, a najgorsze $\mathrm{u}$ chorych z SCLS. Osobną grupę stanowią pacjenci z nieznanym punktem wyjścia choroby nowotworowej, których przeżycie z reguły jest bardzo dobre, pod warunkiem właściwej kontroli kortyzolemii [20].

\section{Opis przypadku}

Opis przypadku dotyczy 68-letniej chorej, obciążonej nadciśnieniem tętniczym, wolem obojętnym, po przebytej operacji usunięcia mięśniaka macicy w 1986 roku, usunięcia pęcherzyka żółciowego w 2006 roku oraz leczeniu operacyjnym z powodu żylaków kończyny dolnej lewej w 2008 roku.

W listopadzie 2009 roku, pacjentka hospitalizowana na Oddziale Chorób Wewnętrznych Szpitala w Chojnicach z powodu wysokich wartości ciśnienie tętniczego ( 200/120 mm Hg), znacznego osłabienia siły mięśniowej, pogorszenia tolerancji wysiłku fizycznego, osłabienia ostrości widzenia, podwójnego widzenia, wzmożonego pragnienia, wielomoczu, obrzęków kończyn dolnych oraz trwającej 3 tygodnie biegunki. $\mathrm{W}$ badaniach laboratoryjnych $\mathrm{z}$ istotnych odchylen stwierdzono hipokaliemię - K 2,0 mEq/1 (zakres wartości referencyjnych 3,5-5,0 mEq/1), dodatkowo badania hormonalne osi tarczycowej sugerowały wtórną niedo- 
czynność tarczycy. W ramach terapii zmodyfikowano leczenie hipotensyjne, włączono suplementację potasu, leczenie odwadniające oraz preparat L-tyroksyny. Za przyczynę opisanych objawów przyjęto głęboką hipokaliemię w przebiegu ostrej biegunki o nieustalonej etiologii.

W październiku 2010 roku, chora ponownie przyjęta na Oddział Chorób Wewnętrznych Szpitala w Chojnicach z powodu podobnych objawów, będących przyczyną hospitalizacji w 2009 roku, z wyjątkiem ostrej biegunki. Oznaczone stężenie potasu 1,8 mEq/1 (zakres wartości referencyjnych 3,5-5,0 mEq/1), oraz jego wydalanie z moczem wynosiło $200 \mathrm{mEq} / \mathrm{d}$. (zakres wartości referencyjnych $25-125 \mathrm{mEq} / \mathrm{d}$.). W ramach diagnostyki wykonano CT jamy brzusznej, w którym opisano guz nadnercza lewego wielkości $24 \times 27 \mathrm{~mm}$ o radiologicznych cechach gruczolaka. Dodatkowo wykonano MRI mózgowia celowane na przysadkę, w którym nie stwierdzono nieprawidłowości. Dostępna dokumentacja/epikryza nie wyjaśniała powodu wykonania badania MRI, możliwe, że było to konsekwencją rozpoznania w czasie poprzedniej hospitalizacji wtórnej niedoczynności tarczycy. W ramach postępowania ponownie zmodyfikowano leczenie hipotensyjne, między innymi dołączono spironolakton $w$ dawce 100 $\mathrm{mg} / \mathrm{d}$., uzyskując dobrą kontrolę ciśnienia tętniczego i stężenia potasu $\mathrm{K}>4,0 \mathrm{mEq} / \mathrm{l}$. Z uwagi na podejrzenie zespołu Conna, chorą skierowano do naszej Kliniki Endokrynologii, Chorób Wewnętrznych, Gdańskiego Uniwersytetu Medycznego.

Planowa hospitalizacja w Klinice Endokrynologii i Chorób Wewnętrznych Uniwersyteckiego Centrum Klinicznego w Gdańsku w kierunku pierwotnego hiperaldosteronizmu odbyła się w lutym 2011 roku. Ze względu na brak możliwości odstawienia leków interferujących $\mathrm{w}$ oś renina-angiotensyna-aldosteron, właściwa ocena laboratoryjna nie mogła być zrealizowana. W oparciu o obraz kliniczny i badania dodatkowe, przyjęto rozpoznanie zespołu Conna za prawdopodobne. Dodatkowo w ramach diagnostyki hormonalnej guza nadnercza, oceniono oś nadnerczową, gdzie wykazano brak rytmu wydzielania kortyzolu, przy prawidłowym jego wydalaniu z moczem i pełnym hamowaniu w teście z $1 \mathrm{mg}$ deksametazonu. Chorą skierowano na adrenalektomię, laparoskopowe usunięcie guza nadnercza lewego wykonano w kwietniu 2011 roku. W badaniu histopatologicznym stwierdzono gruczolaka kory nadnercza.

W październiku 2013 roku chorą ponownie przeniesiono do Kliniki Endokrynologii i Chorób Wewnętrznych UCK w Gdańsku z Oddziału Chorób Wewnętrznych Szpitala w Człuchowie, z podejrzeniem CS. Podmiotowo, od kilku tygodni obecne, opisywane wcześniej, objawy głębokiej hipokaliemii, wysokie
Tabela IV. Oznaczenia laboratoryjne wykonane przed pulmonektomiq

\begin{tabular}{lcc}
\hline Oznaczenie & Wynik & $\begin{array}{c}\text { Wartości } \\
\text { referencyjne }\end{array}$ \\
\hline ACTH 8.00 [pg/ml] & 282 & $<46$ \\
\hline Kortyzol w surowicy $8.00[\mathrm{nmol} / \mathrm{l}]$ & 816 & $101-536$ \\
\hline Kortyzol w surowicy 20.00 [nmol/l] & 780 & $79-478$ \\
\hline $\begin{array}{l}\text { Wolny kortyzol w moczu } \\
\text { [nmol/24h] }\end{array}$ & 10420 & $12-486$ \\
\hline Kortyzol w surowicy 8.00 w teście & 725 & Do interpretacji \\
nocnym z 8 mg deksametazonu & & \\
[nmol/l] & 128 & $17-90$ \\
\hline DHEA-S [ug/dl] & 10 & $0.3-3.5$ \\
\hline Androstendion [ng/ml] & 4.57 & $0.38-1.97$ \\
\hline Testosteron [nmol/l] & 0.182 & $0.34-4.94$ \\
\hline TSH [uU/ml] & 8.88 & $9.01-19.05$ \\
\hline fT $[$ [pmol/l] & 3.38 & $2.63-5.70$ \\
\hline fT ${ }_{3}[\mathrm{pmol} / \mathrm{l}]$ & 0.71 & $2,58-150,53$ \\
\hline FSH [IU/l] & 266.91 & $108.8-557.1$ \\
\hline PRL [mU/l] & 77.90 & $29-204$ \\
\hline IGF-1 [ng/ml] & & \\
\hline & & \\
\hline
\end{tabular}

ciśnienie tętnicze, latwe siniaczenie się, dodatkowo od kilku miesięcy utrata łaknienia i masy ciała rzędu $10 \mathrm{~kg}$ pomimo narastania obrzęków obwodowych oraz chrypka. W badaniach laboratoryjnych tendencja do hipokaliemii i hipernatremii, w ocenie hormonalnej odchylenia typowe dla ACTH-zależnego CS najpewniej w przebiegu EAS. Dodatkowo stwierdzono zaburzenia funkcji płata przedniego przysadki najpewniej wtórne do hiperkortyzolemii (tabela IV).

Ze względu na wydalanie wolnego kortyzolu z moczem przekraczające 4-krotnie górną granicę normy oraz znacznie podwyższone ACTH, nie wykonywano testu potwierdzenia CS — hamowania małą dawką deksametazonu (DEX2). Pozostałe badania laboratoryjne, $\mathrm{w}$ tym markery nowotworowe przedstawiono w tabeli V.

Celem wykluczenia guza przysadki, wykonano badanie MRI mózgowia, w którym nie stwierdzono istotnej patologii. W ramach dalszej diagnostyki wykonano TK klatki piersiowej, które wykazało guz wnęki płuca lewego. Na podstawie materiału pobranego drogą biopsji cienkoigłowej przez ścianę klatki piersiowej, postawiono rozpoznanie raka gruczołowego płuc. Celem dokładniejszej oceny zaawansowania choroby nowotworowej wykonano PET, nie stwierdzając zmian wtórnych. Chorą zakwalifikowano do leczenia operacyjnego, dnia 14.11.2013, po przygotowaniu ketokonazolem, w osłonie hydrokortyzonu, wykonano lewostronną pulmonektomię z limfadenektomią. $\mathrm{Na}$ podstawie oceny preparatu pooperacyjnego posta- 
Tabela V.Oznaczenia laboratoryjne wykonane przed pulmonektomiq

\begin{tabular}{lcc}
\hline Oznaczenie & Wynik & $\begin{array}{c}\text { Wartości } \\
\text { referencyjne }\end{array}$ \\
\hline CEA [ng/ml] & 6,36 & $<5$ \\
\hline CA $125[\mathrm{U} / \mathrm{ml}]$ & 30 & $<35$ \\
\hline CA19.9 [U/ml] & 55,4 & $<37$ \\
\hline AFP $[\mathrm{IU} / \mathrm{ml}]$ & 6,76 & $<11,6$ \\
\hline CgA [ng/ml] & 120,8 & $<100$ \\
\hline Kalcytonina $[\mathrm{pg} / \mathrm{ml}]$ & $<2,0$ & $<11,5$ \\
\hline
\end{tabular}

Tabela VI. Oznaczenia laboratoryjne wykonane po pulmonektomii.

\begin{tabular}{lcc}
\hline Oznaczenie & Wynik & $\begin{array}{c}\text { Wartości } \\
\text { referencyjne }\end{array}$ \\
\hline ACTH 8.00 [pg/ml] & 10 & $<46$ \\
\hline $\begin{array}{l}\text { Kortyzol w surowicy } \\
8.00 \text { [nmol/] }\end{array}$ & 605 & $101-536$ \\
\hline Kortyzol w surowicy & & \\
20.00 [nmol/l] & 405 & $79-478$ \\
\hline Wolny kortyzol w moczu & 394 & $12-486$ \\
[nmol/24h] & & \\
\hline DEX2 [nmol/l] & $<28$ & Do interpretacji \\
\hline DHEA-s [ug/dl] & 15 & $17-90$ \\
\hline Androstendion [ng/ml] & 10 & $0,3-3,5$ \\
\hline Testosteron [nmol/l] & 4,57 & $0,38-1,97$ \\
\hline TSH [uU/ml] & 2,79 & $0,34-4,94$ \\
\hline fT $[\mathrm{pmol} / \mathrm{l}]$ & 13,87 & $9,01-19,05$ \\
\hline fT ${ }_{3}[\mathrm{pmol} / \mathrm{l}]$ & 4,09 & $2,63-5,70$ \\
\hline FSH [IU/l] & 1,30 & $2,58-150,53$ \\
\hline PRL [mU/l] & 266,91 & $108,8-557,1$ \\
\hline IGF-1 [ng/ml] & 193,3 & $29-304$ \\
\hline
\end{tabular}

DEX2 — test hamowania deksametazonem $2 \mathrm{mg} / \mathrm{d} . / 2 \mathrm{dni}$

wiono ostateczne rozpoznanie raka gruczołowego cewkowego z wydzielaniem śluzu, ze względu na zmiany węzłowe i zajęcie tętnicy płucnej, zaawansowanie nowotworu określono jako pT4N1Mx. W ocenie immunohistochemicznej, nie stwierdzono dodatnich barwień na ACTH. Okres pooperacyjny powikłany zapaleniem dolnych dróg oddechowych skutecznie leczony antybiotykiem. W wykonywanych systematycznie badaniach laboratoryjnych w pierwszych dniach po przeprowadzonej operacji utrzymywała się hiperkortyzolemia ACTH-zależna pomimo szybkiej redukcji, a następnie całkowitego odstawienia hydrokortyzonu. $\mathrm{Z}$ tego powodu, po opanowaniu infekcji układu oddechowego przeprowadzono test hamowania $\mathrm{z}$ małą dawką deksametazonu (DEX2), uzyskując hamowanie kortyzolu w surowicy $<50 \mathrm{nmol} / \mathrm{l}$. Pozostałe badania hormonalne przeprowadzone po leczeniu operacyjnym przedstawiono w Tabeli VI.

W kwietniu 2014 roku chorą przyjęto na Oddział Onkologii celem paliatywnej radioterapii z powodu przerzutów do kości.

\section{Dyskusja}

Przedstawiony przypadek kliniczny budzi wiele wątpliwości. Najważniejsze pytania, które się nasuwają, to: Czy mamy do czynienia z tak zwanym cyklicznym CS? Czy rozpoznanie raka płuc mogło być postawione 4 lata wcześniej? Czy postęp rozpoznanej choroby nowotworowej mógł być tak wolny? Czemu nie obserwowano typowej dla wyleczonych pacjentów z CS hipokortyzolemii w okresie pooperacyjnym (brak konieczności substytucji hydrokortyzonem)?

Biorąc pod uwagę niemal identyczne objawy będące przyczyną kilkukrotnej hospitalizacji pacjentki, skojarzone z głęboką hipokaliemią oraz odchyleniami sugerującymi wtórną niedoczynność tarczycy (podstawowe badania laboratoryjne wykonane $\mathrm{w}$ trakcie każdej z wspomnianej hospitalizacji), można by zweryfikować rozpoznanie, stawiając diagnozę zespołu Cushinga 4 lata przed rozpoznaniem raka płuca. Tym samym rozpoznanie opisywanego w piśmiennictwie cyklicznego CS byłoby prawdopodobne. Interesującym jest fakt, że objawy, które ex post można wiązać $\mathrm{z}$ hiperkortyzolemią, zawsze występowały w na wiele lat przed postawieniem ostatecznego rozpoznania. Wątpliwość powstaje w przypadku rozpoznania CS w przebiegu EAS na podłożu jednego z bardziej agresywnych nowotworów złośliwych — raka płuca. Alternatywna diagnoza to współistnienie dwóch rzadkich endokrynopatii: zespołu Conna i CS. Możliwym wytłumaczeniem braku hipokortyzolemtii po przeprowadzonym leczeniu operacyjnym byłaby typowa reakcja spotykana u ludzi zdrowych zależna od stresu okołooperacyjnego i stwierdzonej infekcji. Tymczasem u chorych wyleczonych z CS, leczenie substytucyjne glikokortykosteroidem musi być prowadzone przez wiele miesięcy po operacji, czasem nawet nie udaje się takiego leczenia odstawić w ogóle.

\section{Wnioski}

Zespół Cushinga w przebiegu EAS stanowi dobry przykład właściwego postępowania medycznego, począwszy od zebrania dokładnego wywiadu i przeprowadzenia badania fizykalnego, wykonania szeregu badań dodatkowych, aż po wdrożenie właściwej terapii. Jak żadne inne zagadnienie, stanowi nie lada wyzwanie 
kliniczne, o czym świadczy duża grupa chorych o nieustalonym punkcie wyjścia choroby, pomimo możliwej do wykonania szerokiej diagnostyki. Ze względu na liczne powikłania hiperkortyzolemii, między innymi infekcyjne i żylno-zakrzepowe, będące główną przyczyną zgonu chorych na CS, właściwe rozpoznanie oraz leczenie należy wdrożyć jak najszybciej. Tym samym podejrzenie CS wymaga wstępnej weryfikacji, czyli wykonania jednego z kilku dostępnych ambulatoryjnie badań przesiewowych. W przypadku wątpliwości lub uzyskania wyniku pozytywnego, chorego należy skierować do ośrodka referencyjnego. 